\title{
RETRACTED ARTICLE: Linkage between International Trade, Financial Development and Economic Growth in Saudi Arabia: \\ An Application of the Combined Cointegration Approach
}

\author{
Faisal Faisal * $\quad$ Turgut Tursoy ${ }^{\dagger} \quad$ Nil Gunsel Resatoglu ${ }^{\ddagger}$
}

\begin{abstract}
The purpose of this study is to analyze the linkage between economic growth, financial development, and international trade for Saudi Arabia over the period of 1968-2015. The integration order among the series was analyzed by using structural break unit root tests. The longrun relationship was examined by using the ARDL bounds testing approach. The robustness of the $A R D L$ bounds testing approach was confirmed by using the Bayer-Hanck combined cointegration method. The results confirm the long-run relationship among the variables. International trade appears to be the driver of economic growth, while financial development affects economic growth negatively in both the short-run and the long-run. However, the impact of capital was insignificant in both the short-run and long-run. Finally, the results of the Granger causality test confirmed the feedback hypothesis between financial development and economic growth on one hand, and capital and economic growth on the other hand. However, a short-run unidirectional causality was discovered from exports to economic growth, which validates the export-led growth hypothesis in this study.
\end{abstract}

Keywords: Saudi Arabia, Financial development, trade, combined cointegration.

\footnotetext{
${ }^{*} \mathrm{PhD}$ Candidate, Department of Banking and Finance, Faculty of Economics and Administrative Sciences, Near East University, North Cyprus, E-mail:faisal.faisal@neu.edu.tr

$\dagger$ Vice Chair and Assistant Professor, Department of Banking \& Finance, Near East University, North Cyprus.

${ }^{\ddagger}$ Chair and Assistant Professor, Department of Banking \& Finance, Near East University, North Cyprus. The Authors are thankful to the editor and the anonymous reviewers for their helpful comments and suggestions on the earlier version of the manuscript.
} 